\title{
Quantitative analysis of the Arkhangelskiella cymbiformis Group and Biostratigraphic usefulness in the North Sea Area
}

\author{
O. VAROL
}

The Robertson Group plc, Llandudno. Gwynedd LI.30 ISA U.K.

\begin{abstract}
Based upon a combination of biometric and quantitative analysis on the Arkhangelskiclla (ymbiformis group, six additional datums were obtained in the Campanian to Maastrichtian interval of the North Sea area. These datums are in ascending order: 1. first common to abundance occurrence of $A$ (ymbiformis (Var. NT); 2. lasi common to abundance occurrence of A. cymbiformis (Var. NT): 3. first common to abundant occurrence of $A$. cymbiformis (var. N); 4. first common to abundant occurrence of $A$. cymbiformis (Var. W); 5. last common to abundant occurrence of $A$. cymbiformis (Var. N); and 7. last common to abundant occurrence of $A$. cymbiformis (Var. W). The width of the shield is taken as a main criterion for biometric analysis.
\end{abstract}

\section{INTRODLCTION}

During a detailed study of Campanian to Maastrichtian sediments from various well sections in the North Sea area, a biometric and quantitative study was performed on the Arkhangelskiella cymbiformis group. This study was initiated because of the need for a more precisely correlatable biostratigraphic subdivision of the Campanian to Maastrichtian sequence of the North Sea area than is offered by conventional methods.

Identification of species of the genus Arkhangelskiella has mainly been based on the number of pores in the central area as well as the number of the shields and the relative diameters of the shields. It is, however, impossible to distinguish these criteria consistently under the light microscope particularly in overgrown assemblages, as encountered in the study area, in spite of their remarkable abundances. A simple biometric technique which can be applied by any nannopalaeontologist was therefore employed here. This study, moreover, is itself proof that the quantified biometric variations of the Arkhangelskiella rymbiformis group provide correlatable datums initially in closely spaced sections within North Sea. The results of this study have also been applied in several wells within the different parts of the North Sea area and seem to work quite well, however, more research is needed in order to test the correlatable value of these datums throughout the North Sea area.

The main aim of this paper is to demonstrate the methodology applied in a certain limited area in order to obtain finer subdivision, and to prove that an innovative approach which breaks the rules of traditional biostratigraphy can be rewarding.

\section{PREVIOUS WORK}

The potential use of biometric studies for nannofossils was first demonstrated by nannopalaeontologists as early as the early 1960s. Stradner(1963) mentioned that variation in the size of nannofossils can be used for stratigraphic and palaeoenvironmental purposes. To our knowledge, the first biometric studies were undertaken by Perch-Nielsen (1968) whocarried out biometric studies on Cribrosphaerellaehrenbergii, Cribrosphaerella hillii and Nephrolithus frequens in Maastrichtian sediments in Denmark. Since then several biometric studies have been published including Lauer's (1975) work on the Cretaceous Genera Aspidolithus, Broinsonia, Arkhangelskiella and Gartnerago and studies by Verbeek (1977) and Crux (1982) on the genus Broinsonia. Perch-Nielsen (1985) mentions a general increase in the mean length of $A$. cymbiformis in Campanian to Maastrichtian sediments. Girgis (1989) carried out a detailed biometric study on the Arkhangelskiclla group and established datums based upon mean length variation appearances and extinctions of certain type identified by their length of this group in the sediments of Egypt and integrated these datums with the available conventional datums. Several biometric studies were also performed on of Tertiary forms including Backman (1980) on the genus Reticulofenestra and Samtleben $(1978,1980)$ on the genus Gephyrocapsa.

\section{METHODS}

In the present study only core and sidewall core samples from the well sections were studied. Analysis was carried out on smear slides. Since it inconsistently altered the relative frequency of the morphotypes of $A$. cymbiformis and the abundance of other species in the samples the centrifuge technique was abandoned.

For biometric analysis, the width of shield in each specimen is measured and the abundance recorded on a longitudinal traverse $(300$ fields of view) on a smear slide.

\section{BIOMETRIC VARIATION OF Arkhangelskiella cymbiformis GROUP}

Three variations of $A$. cymbiformis were distinguished under the light microscope based on the measurement of the width of the shiclds. The frequencies of these variations led to the identification of six datums in addition to those obtained using traditional methods. The zonation scheme of Mortimer (1987) is adopted in this study. The average frequencies of A. cymbiformis group are given in Fig. 1 . 
A. (vmbiformis (Var. W): this is the wide shield variation. The width of the shield is equal to or greater than $2 \mu \mathrm{m}$. This variant is common to abundant only within the upper range of Nephrolithus ficequens, although it is rarely present throughout Campanian to Maastrichtian sediments.

A. cymbiformis (Var.N): This is the narrow shield variation. The width of the shield is less than $2 \mu \mathrm{m}$. This variant is also present throughout Campanian to Maastrichtian sediments but becomes common to abundant between the extinction of Bifidalithus geminicatillus Varol (in prep.) and the middle part of the range of Nephrolithus frequens.

A. cumbiformis (Var. NT): This is the narrow and thin shield variation. The width of the shield is usually about 1 $1.5 \mu \mathrm{m}$. The shields become much thinner towards the outer edge, possibly as a result of having much larger distal shields than proximal ones. This variant may be initially difficult to separate from A. cumbiformis (Var. N) but is easily distinguished from it under cross polarised light since shields are less affected by overgrowth and much thinner towards the outer edge where they do not appear to be not as regular as in A. cymbiformis (Var. N). Using a gypsum plate, blue are much darker while yellows are lighter than is the case in $A$. cymbiformis (Var.N). This variation is also present throughout Campanian to Maastrichtian sediments but becomes common to abundant between the evolutionary appearance of the Broinsonia parcagroup and the extinction of Storerius (o)ronatus and Tranolithus minimus.

\section{CONCLUSION}

The application of biometric and quantitative methods to the study of the A.cymbiformis group proved to be extremely useful in subdividing the stratigraphic range of $N$. frequens where this species often extremely rare or absent due to the diagenetic alterations.

The proportions of different varieties of $A$. c vmbiformis in a given sample are an indication of the extend of reworking in that sample and help to distinguish basal Danian from Maastrichtian sediments.

\section{ACKNOWLEDGEMENTS}

I am grateful to Dr. J. F. Laing and Dr. M.H. Girgis for their review of the manuscript and their useful suggestions. The author wishes to acknowledge the funding of the cost of the colour plate by Robertson Group plc.

\section{Manuscript received April 1989}

\section{Manuscript accepted September 1989}

\section{REFERENCES}

Backman, J. 1980 Miocene-Pliocene nannofossils and sedimentation rates in the Hatton-Rockall basin. NE Atlantic Ocean. Acta Unir. Stockholm Contrib. Geol, 36 (1), 1-91.

Crux, J. A. 1982. Upper Cretaceous (Cenomanian to
Campanian) calcareous nannofossils. In: Lord A. R. (Ed.), A stratigraphical inder of calcareoms namnofossils, British Micropal. Soc. 81-135.

Lauer, G. 1975. Evolutionary trends in the Arkhangelskiellaceae (calcareous nannoplankton) of the Upper Cretaceous of Central Oman, SE Arabia. Arch. Sci. Geneva, 28, 259-262.

Mortimer, C.P. 1987. Upper Cretaceous nannofossil biostratigraphy of the southern Norwegian and Danish North Sea areas. Abh. Geol. B. - A., 39, 143-175

Perch-Nielsen, K. 1968. Der Feinbau und die Klassifikation der Coccolithen aus dem Maastrichtien von Danemark. $K$. Dan. Vidensk. Solsk. Biol. Skr., 16 (1), 1-96.

Perch-Nielsen, K. 1985. Mesozoic calcareous nannofossils. In: Bolli, H.M. Saunders, J.B. and Perch-Nielsen, K. (Eds).. Plankton Stratigraphy, Cambridge University Press, Cambridge, 329-426.

Samtleben, C. 1978. Pliocene-Pleistocene coccolith assemblages from the Sierra Leone Rise - Site 366, Leg 41. Initial Rep. Deep Sea Drill. Proj., 41, supplement, 913-931.

Samtleben, C. 1980. Die Evolution de CoccolithophoridenGattung Gephvocapsa nach Befunden im Atlantik. Palaontol. Z., 54 (1.2), 91-127.

Strandner, H. 1963. New contributions to Mesozoic stratigraphy by means of nannofossils. Proceedings 6 th World Petrol. Congr. Sect. I, paper 4 (preprint), 1-16.

Varol, $\mathrm{O}$ (in prep.) New Cretaceous and Tertiary calcareous nannofossils.

Verbeek, J.W., 1977. Calcareous nannoplankton biostratigraphy of Middle and upper Cretaceous deposits in Tunisia, Southern Spain and France. Utrecht Micropaleont. Bull., 16, 1-157.

The full references of species cited in this study and not included here may be found in Perch-Nielsen (1985). 


\section{A. cymbiformis (var. W)}
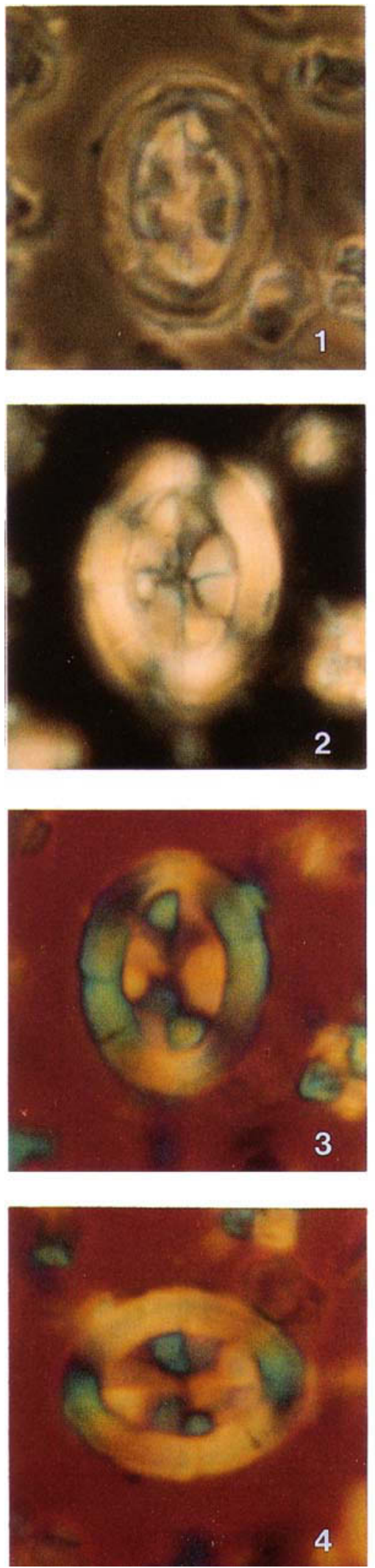

A. cymbiformis (var. N)
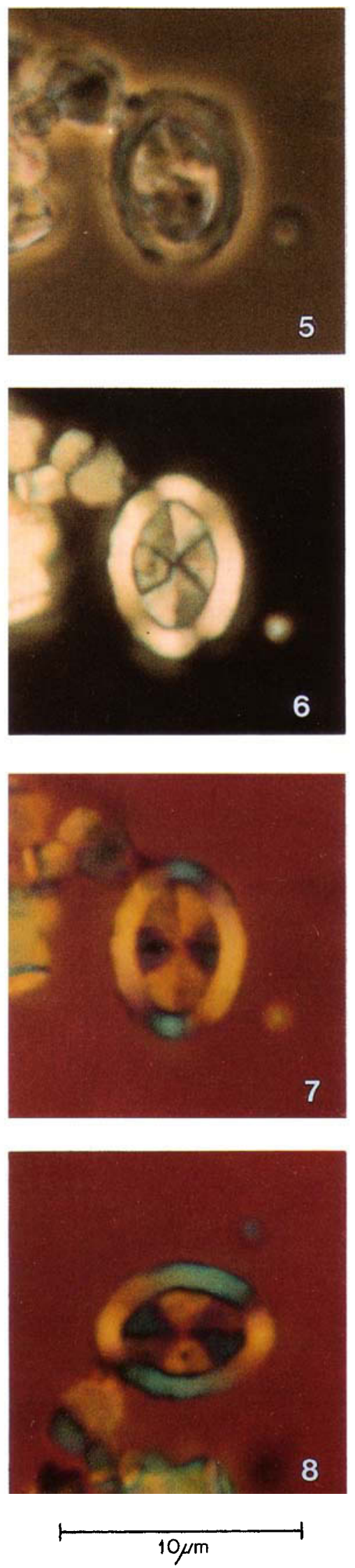

A. cymbiformis (var. N T)
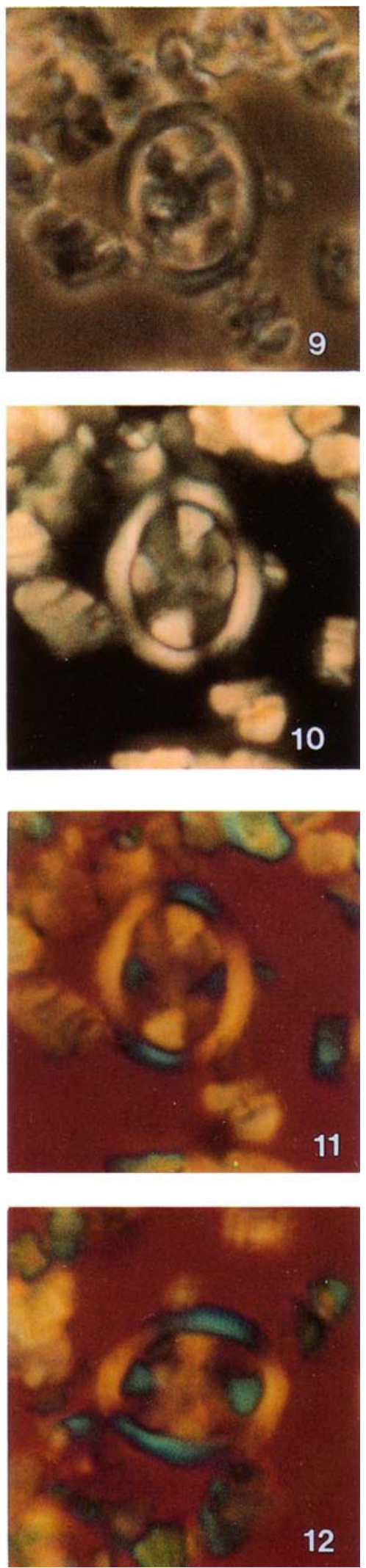


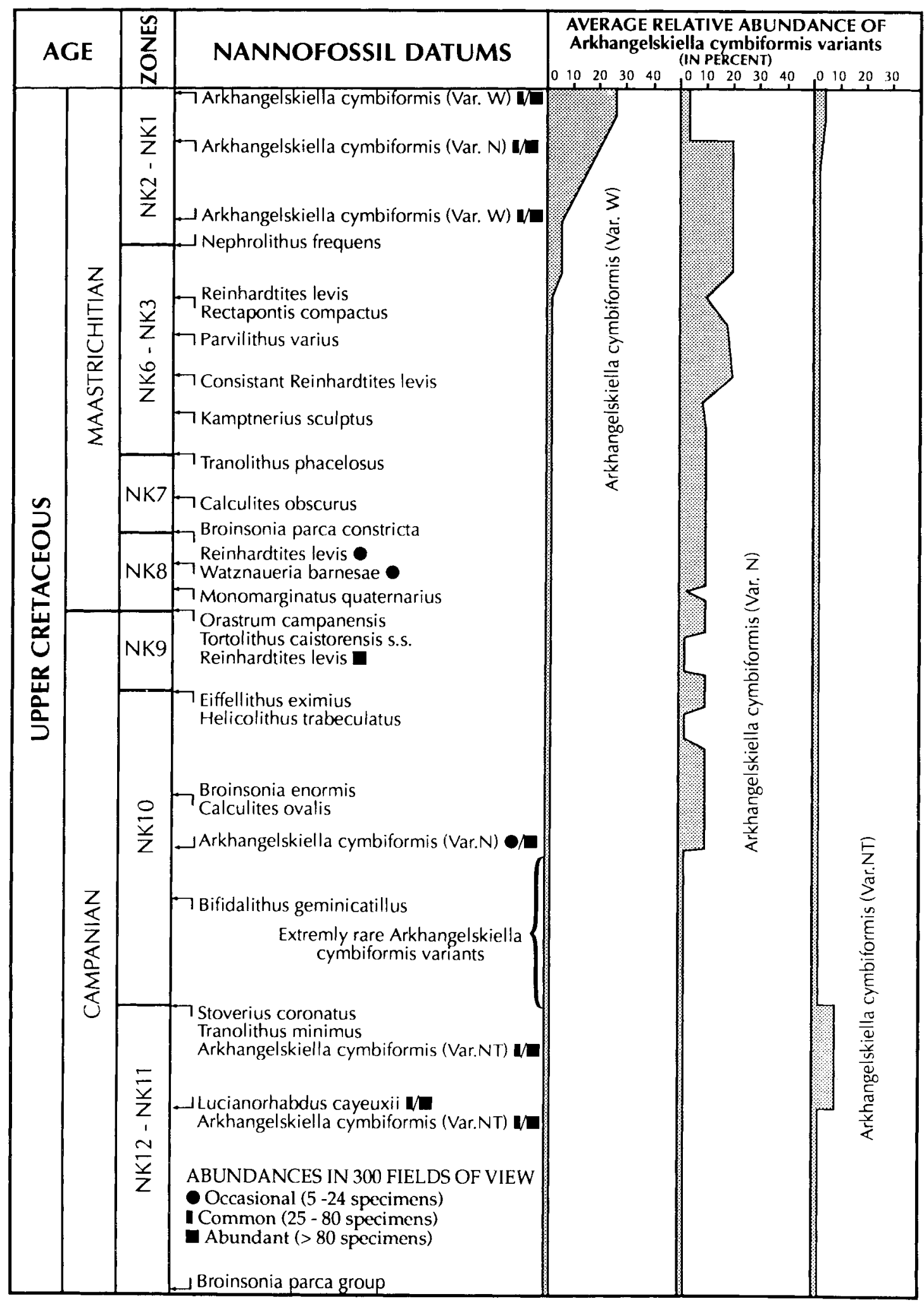

Fig. 1. Nannofossil datums and average relative abundances on the A.cymbiformis group in the Campanian to Maastrichtian interval in the North Sea area. NK Zones after Mortimer (1987). (Vertical thickness of the zones have no chronostratigraphic inference). 